\title{
Genetic testing for lymphatic malformations with or without primary lymphedema
}

\author{
Stefano Paolacci ${ }^{1}$, Yeltay Rakhmanov ${ }^{2}$, Paolo Enrico Maltese ${ }^{2 \star}$, Alessandra Zulian ${ }^{1}$, Sandro Michelini ${ }^{3}$ \\ and Matteo Bertelli ${ }^{1,2}$
}

\begin{abstract}
Lymphatic malformations (LMs) show phenotypic variability, as well as clinical and genetic heterogeneity. Inheritance is autosomal dominant, recessive or X-linked and major genes involved in predisposition for LMs are continuously being discovered. The literature also indicates that somatic mutations play an important role in the development of LMs. In fact, activating somatic mutations in PIK3CA have been reported in lymphatic endothelial cells obtained from patients with different kinds of LM. This Utility Gene Test was developed on the basis of an analysis of the literature and existing diagnostic protocols. It is useful for confirming diagnosis, as well as for differential diagnosis, couple risk assessment and access to clinical trials.
\end{abstract}

Keywords: Primary lymphatic malformations, germline mutations, somatic mutations, EBTNA UTILITY GENE TEST

'MAGI Euregio, Bolzano, Italy

${ }^{2}$ MAGI's Lab, Rovereto, Italy

${ }^{3}$ Department of Vascular Rehabilitation, San Giovanni Battista Hospital, Rome, Italy

*Corresponding author: P. E. Maltese E-mail: paolo.maltese@assomagi.org DOI: 10.2478/ebtj-2018-0024
(C) 2018 Authors. This work was licensed under the Creative Commons AttributionNonCommercial-NoDerivs 3.0 License.

\section{Lymphatic malformations with or without primary lymphedema} (Other synonyms: Primary lymphatic malformations are a group of diseases; see phenotypic variants)

\section{General information about the disease}

The term "lymphatic malformations" refers to a broad range of lymphatic system defects (aplasia, hypoplasia and hyperplasia of lymphatic channels and nodes (1), or localized unifocal lesions consisting of dilated lymphatic channels filled with lymph but disconnected from the rest of the lymphatic system (2)). In many cases these defects cause lymphedema (abnormal accumulation of interstitial fluid due to inefficient uptake and reduced lymphatic flow); in other cases lymphatic malformations are not associated with lymphedema. In the past, lymphatic malformations (LMs) and primary lymphedema were considered two different entities, however according to the Hamburg classification, primary lymphedema is a clinical manifestation of LMs appearing in later stages of lymphangiogenesis (truncular LMs) (1), whereas extratruncular lesions, known as cystic/ cavernous lymphangiomas, develop during earlier stages of lymphangiogenesis (1). The prevalence of truncular and extratruncular LMs is 1-5/10,000.

In the first step of diagnosis, clinical history and physical examination (3) of patients with LMs should reveal whether the malformation is truncular, extratruncular or syndromic, and if the disorder is inherited or sporadic (4). Lymphoscintigraphy has proved extremely useful for depicting specific lymphatic abnormalities (3). Radioactive colloid is injected into the toe web spaces and uptake by the ilioinguinal nodes is measured at intervals. Lymphoscintigraphy is performed to determine if there is a lack of uptake of radioactive tracer. Other diagnostic tools used to elucidate lymphangiodysplasia/lymphedema syndromes (also in newborns and children) include lymphangioscintigraphy, magnetic 
resonance imaging (MR lymphography and MR angiography), computed tomography (CT), CT lymphograms, 3-D oil contrast lymphography, CT-SPECT, ultrasonography, indirect lymphography, near infrared fluorescent imaging (also known as ICG lymphography) and fluorescent microlymphangiography (3). Lymphoscintigraphy is not always essential for diagnosis and one can proceed directly to molecular testing (5).

Differential diagnosis should include hereditary lymphedema; lymphedema-distichiasis; Emberger syndrome; hypotrichosis-lymphedema-telangiectasia syndrome; microcephaly with or without chorioretinopathy, lymphedema and mental retardation; lymphedema-choanal atresia; Hennekam lymphangiectasia-lymphedema syndrome; anhidrotic ectodermal dysplasia with immunodeficiency, osteopetrosis and lymphedema; congenital lipomatous overgrowth, vascular malformations and epidermal nevi syndrome; and Klippel-Trenaunay syndrome.

LMs are associated with several conditions characterized by allelic and locus heterogeneity and different modes of inheritance. Inheritance can be autosomal dominant, autosomal recessive or X-linked recessive. Genes involved in a predisposition to lymphedema triggered by surgery have also been reported $(6,7)$.

\section{Autosomal dominant non-syndromic LMs}

- hereditary lymphedema 1A (LMPH1A, OMIM disease 153100) - FLT4 (OMIM gene 136352) (4);

- hereditary lymphedema 1C (LMPH1C, OMIM disease 613480) - GJC2 (OMIM gene 608803) (8);

- hereditary lymphedema 1D (LMPH1D, OMIM disease 615907) - VEGFC (OMIM gene 601528) (9);

- bilateral lymphedema of the lower limbs (OMIM disease not available) - CELSR1 (OMIM gene 604523) and HGF (OMIM gene 142409) $(7,10)$.

\section{Autosomal dominant syndromic LMs}

- lymphedema-distichiasis (OMIM disease 153400) - FOXC2 (OMIM gene 602402) (11);

- primary lymphedema with myelodysplasia or Emberger syndrome (OMIM disease 614038) - GATA2 (OMIM gene 137295) (12);

- hypotrichosis-lymphedema-telangiectasia syndrome (HLTS, OMIM disease 607823) - SOX18 (OMIM gene 601618) (13);

- microcephaly with or without chorioretinopathy, lymphedema or mental retardation (MCLMR, OMIM disease 152950) - KIF11 (OMIM gene 148760) (14);

- oculodentodigital dysplasia (ODDD, OMIM disease 164200) - GJA1 (OMIM gene 121014) (15);

- nonimmune hydrops fetalis and/or atrial septal defect (HFASD, OMIM disease 617300) - EPHB4 (OMIM gene 600011) (16);

- Noonan syndrome 1, 3, 4, 6, 8 (NS, OMIM disease 163950 , 609942, 610733, 613224, 615355) - PTPN11 (OMIM gene 176876), KRAS (OMIM gene 190070), SOS1 (OMIM gene
182530), NRAS (OMIM gene 164790), and RIT1 (OMIM gene 609591) (17-21);

- Noonan-like syndrome with or without juvenile myelomonocytic leukemia (NSLL, OMIM disease 613563) - CBL (OMIM gene 165360) (22);

- Costello syndrome (OMIM disease 218040) - HRAS (OMIM gene 190020) (23);

- Noonan-like syndrome with loose anagen hair (NSLH, OMIM disease 607721) - SHOC2 (OMIM gene 602775) (21);

- cardiofaciocutaneous syndrome 1 (OMIM disease 115150) $B R A F$ (OMIM gene 164757) (24).

\section{Autosomal recessive syndromic LMs}

- hypotrichosis-lymphedema-telangiectasia syndrome (HLTS, OMIM disease 607823) - SOX18 (OMIM gene 601618) (13);

- lymphedema-choanal atresia (OMIM disease 613611) PTPN14 (OMIM gene 603155) (25);

- Hennekam lymphangiectasia-lymphedema syndrome 1 and 2 (HKLLS1 and 2, OMIM disease 235510 and 616006) - CCBE1 (OMIM gene 612753) or FAT4 (OMIM gene 612411) $(26,27)$;

- hereditary lymphedema 3 (LMPH3, OMIM disease 616843) - PIEZO1 (OMIM gene 611184) (28).

- Recently, a new form of HKLLS (HKLLS3), caused by lossof-function mutations in ADAMTS3 (OMIM gene 605011), has been described (29).

\section{$\mathrm{X}$-linked recessive syndromic LMs}

- anhidrotic ectodermal dysplasia with immunodeficiency, osteopetrosis and lymphedema (OLEDAID, OMIM disease 300301) - IKBKG (OMIM gene 300248) (30).

Diseases with paradominant inheritance (as consequence of a second-hit, germline + somatic, variation) associated with LMs

- RASA1-related lymphatic malformations (OMIM disease not available) - RASA1 (OMIM gene 139150) (31, 32);

- congenital chylothorax (OMIM disease 603523) - ITGA9 (OMIM gene 603963) (33).

Diseases with sporadic onset, due to de novo somatic variations, associated with $\mathrm{LMs}$

- PIK3CA-associated syndromes (OMIM disease not available) - PIK3CA (OMIM gene 171834); the following disorders are included in this spectrum: isolated lymphatic malformations (OMIM disease not available), congenital lipomatous overgrowth, vascular malformations and epidermal nevi syndrome (CLOVES, OMIM disease 612918), Klippel-Trenaunay syndrome (KTS, OMIM disease 149000) and fibro-adipose vascular anomaly (FAVA, OMIM disease not available) (34);

- Proteus syndrome (OMIM disease 176920) caused by somatic mutations in AKT1 (OMIM gene 164730) (35). 


\section{Other likely genes}

ADM (OMIM gene 103275), CALCRL (OMIM gene 114190), CDH5 (OMIM gene 601120), PDPN (OMIM gene 608863), RAMP2 (OMIM gene 605154), NRP2 (OMIM gene 602070), PROX1 (OMIM gene 601546), GJA4 (OMIM gene 121012), CYP26B1 (OMIM gene 605207), ITGA5 (OMIM gene 135620), MAP4K4 (OMIM gene 604666), ASPP1 (OMIM gene 606455), ARAP3 (OMIM gene 606647), CDK5 (OMIM gene 123831), NFATC1 (OMIM gene 600489), TIE1 (OMIM gene 600222), ANGPT2 (OMIM gene 601922), DCHS1 (OMIM gene 603057), NR2F2 (OMIM gene 107773), SMARCA4 (OMIM gene 603254), LPAR4 (OMIM gene 300086), FOXC1 (OMIM gene 601090), EMILIN1 (OMIM gene 130660), RORC (OMIM gene 602943), SVEP1 (OMIM gene 611691), SDC4 (OMIM gene 600017), PECAM1 (OMIM gene 173445), VANGL2 (OMIM gene 600533), FLT1 (OMIM gene 165070), NOTCH1 (OMIM gene 190198), RELN (OMIM gene 600514), EFNB2 (OMIM gene 600527), SEMA3A (OMIM gene 603961), NRP1 (OMIM gene 602069), PLXNA1 (OMIM gene 601055), PROX1 (OMIM gene 601546), FABP4 (OMIM gene 600434), SOX17 (OMIM gene 610928), VCAM1 (OMIM gene 192225), MET (OMIM gene 164860), FOXC2-AS1 (OMIM gene not available), LZTR1 (OMIM gene 600574), SOS2 (OMIM gene 601247), MAP2K2 (OMIM gene 601263), MAP2K1 (OMIM gene 176872), PPP1CB (OMIM gene 600590), RAF1 (OMIM gene 164760).

Pathogenic variants may include missense, nonsense, splicing, small insertions, small deletions, small indels, gross insertions, duplications and complex rearrangements.

\section{Aims of the test}

- To determine the gene defect responsible for the disease;

- To confirm clinical diagnosis;

- To assess the recurrence risk and perform genetic counselling for at-risk/affected individuals.

\section{Test characteristics}

\section{Specialist centers/Published guidelines}

The test is listed in the Orphanet database and is offered by 22 accredited medical genetic laboratories in the EU, and in the GTR database, offered by 7 accredited medical genetic laboratories in the US.

Guidelines for clinical use of the test are described in disease-specific chapters of Genetics Home Reference (ghr.nlm. nih.gov) and Gene Reviews (36).

\section{Test strategy}

Clinically distinguishable syndromes can be analyzed by sequencing only those genes known to be associated with that specific disease using Sanger or Next Generation Sequencing (NGS); if the results are negative, or more generally if clinical signs are ambiguous for diagnosis, a multi-gene NGS panel is used to detect nucleotide variations in coding exons and flanking introns of the above genes.

- If the disorder is familial, the test is performed to identify pathogenic germline variants.
- If the disease is sporadic, the first step is to identify germline variants and check the possibility of a dominant de novo mutation.

- If the test is negative or if only a single germline variant in a paradominant gene (RASA1 or ITGA9) is found, the second step is to analyze affected tissues to find de novo somatic mutations that could be present only at the site of the malformation.

The test for paradominant (RASA1 or ITGA9) and de novo (AKT1 and PIK3CA) somatic variations is to compare results obtained from germinal lineage (blood or saliva specimens) and affected tissue. For variant selection, a cut-off value (related to biopsy and blood results) is used, and if the variant frequency is higher than the cut-off value it is considered for further analysis. The cut-off depends on tissue quality, extraction method, biocomputing software and other parameters. Potentially causative variants need to be verified by further means (e.g. cloning + Sanger sequencing, Sanger sequencing, minisequencing).

Genetic analysis should be extended to relatives when the test is positive in familial cases or when a de novo germline variant is found that could be inherited by offspring. Potentially causative variants and regions with low coverage are Sanger-sequenced. Sanger sequencing is also used for family segregation studies.

Multiplex Ligation Probe Amplification (MLPA) is used to detect duplications and deletions in FOXC2, GATA2, NRAS, HRAS and BRAF.

To perform molecular diagnosis, a single sample of biological material is normally sufficient. This may be $1 \mathrm{ml}$ peripheral blood in a sterile tube with $0.5 \mathrm{ml} \mathrm{K}$ EDTA or $1 \mathrm{ml}$ saliva in a sterile tube with $0.5 \mathrm{ml}$ ethanol $95 \%$. Sampling rarely has to be repeated.

A frozen intra-lesional biopsy specimen, in addition to blood or saliva, is necessary to test for somatic variations.

Gene-disease associations and the interpretation of genetic variants are rapidly developing fields. It is therefore possible that the genes mentioned in this note may change as new scientific data is acquired. It is also possible that genetic variants today defined as of "unknown or uncertain significance" may acquire clinical importance.

\section{Genetic test results \\ Positive}

Identification of pathogenic variants in the above genes confirms the clinical diagnosis and is an indication for family studies.

A pathogenic variant is known to be causative for a given genetic disorder based on previous reports or predicted to be causative based on loss of protein function or expected significant damage to protein or protein/protein interactions. In this way it is possible to obtain a molecular diagnosis in new/other subjects, establish the risk of recurrence in family members and plan preventive and/or therapeutic measures.

\section{Inconclusive}

Detection of a variant of unknown or uncertain significance 
(VUS): a new variation without any evident pathogenic significance or a known variation with insufficient evidence (or with conflicting evidence) to indicate it is likely benign or likely pathogenic for a given genetic disorder. In these cases, it is advisable to extend testing to the patient's relatives to assess variant segregation and clarify its contribution. In some cases, it could be necessary to perform further examinations/tests or to do a clinical reassessment of pathological signs.

\section{Negative}

The absence of variations in the genomic regions investigated does not exclude a clinical diagnosis but suggests the following possibilities:

- Alterations that cannot be identified by sequencing, such as large rearrangements that cause loss (deletion) or gain (duplication) of extended gene fragments.

- Sequence variations in genomic regions not investigated by the test, such as regulatory regions, 5'- and 3'-UTR) and deep intronic regions.

- Variations in other genes not investigated by the present test.

\section{Unexpected}

Unexpected results may emerge from the test, for example information regarding consanguinity, absence of family correlation or other genetically-based diseases.

\section{Risk for progeny}

If the identified pathogenic variant has autosomal dominant transmission, the probability that an affected carrier transmit the disease variant to his/her children is $50 \%$ in any pregnancy, irrespective of the sex of the child conceived.

In autosomal recessive mutations, both parents are usually healthy carriers. In this case, the probability of transmitting the disorder to the offspring is $25 \%$ in any pregnancy of the couple, irrespective of the sex of the child. An affected individual generates healthy carrier sons and daughters in all cases, except in pregnancies with a healthy carrier partner. In these cases, the risk of an affected son or daughter is $50 \%$.

In X-linked recessive inheritance, affected males transmit the pathogenic variant to their daughters and the probability that a female carrier transmit the pathogenic variant to her offspring is $50 \%$ in any pregnancy irrespective of the sex of the child conceived. Females who inherit the pathogenic variant are carriers and usually unaffected. Males who inherit the pathogenic variant are affected.

De novo somatic variations cannot be inherited or transmitted. In paradominant inheritance, only the germline genetic variant is transmitted in an autosomal dominant fashion and the probability that carriers transmit the germline pathogenic variant to their children is $50 \%$ in any pregnancy, irrespective of the sex of the child conceived.

\section{Limits of the test}

The test is limited by current scientific knowledge regarding the genes and diseases.
Analytical sensitivity (proportion of positive tests when the genotype is truly present) and specificity (proportion of negative tests when the genotype is not present)

NGS Analytical sensitivity $>99.99 \%$, with a minimum coverage of 10X; Analytical specificity $99.99 \%$.

SANGER Analytical sensitivity $>99.99 \%$; Analytical specificity 99.99\%.

MLPA Analytical sensitivity $>99.99 \%$; Analytical specificity $99.99 \%$.

Clinical sensitivity (proportion of positive tests if the disease is present) and clinical specificity (proportion of negative tests if the disease is not present)

Clinical sensitivity is estimated at about $25 \%$ (2).

Clinical specificity: data not available.

\section{Prescription appropriateness}

The genetic test is appropriate when:

a) the patient meets the diagnostic criteria for LMs;

b) the sensitivity of the test is greater than or equal to that of tests described in the literature.

\section{Clinical utility}

Clinical management

Utility

Confirmation of clinical diagnosis

Yes

Differential diagnosis

Yes

Couple risk assessment

Yes

Availability of clinical trials can be checked on-line at https://clinicaltrials.gov/

\section{References}

1. Lee BB, Villavicencio JL. Primary lymphoedema and lymphatic malformation: are they the two sides of the same coin? Eur J Vasc Endovasc Surg 2010; 39(5): 646-53.

2. Brouillard P, Boon L, Vikkula M. Genetics of lymphatic anomalies. J Clin Invest 2014; 124(3): 898-904.

3. ISL. The diagnosis and treatment of peripheral lymphedema: 2016 consensus document of the international society of lymphology. Lymphology 2016; 49: 170-84.

4. Connell FC, Gordon K, Brice G, Keeley V, Jeffery S, Mortimer PS, Mansour S, Ostergaard P. The classification and diagnostic algorithm for primary lymphatic dysplasia: An update from 2010 to include molecular findings. Clin Genet 2013; 84(4): 303-14.

5. Brice GW, Mansour S, Ostergaard P, Connell F, Jeffery S, Mortimer P. Milroy Disease. 2006 Apr 27 (updated 2014 Sep 25). In: Adam MP, Ardinger HH, Pagon RA, Wallace SE, Bean LJH, Stephens K, Amemiya A, editors. GeneReviews ${ }^{\oplus}$ (Internet). Seattle (WA): University of Washington, Seattle; 1993-2018.

6. Finegold DN, Baty CJ, Knickelbein KZ, Perschke S, Noon SE, Campbell D, Karlsson JM, Huang D, Kimak MA, Lawrence EC, Feingold E, Meriney SD, Brufsky AM, Ferrell RE. Connexin 47 mutations increase risk for secondary lymphedema following breast cancer treatment. Clin Cancer Res 2012; 18(8): 2382-90.

7. Finegold DN, Schacht V, Kimak MA, Lawrence EC, Foeldi E, Karlsson $J M$, Baty CJ, Ferrell RE. HGF and MET mutations in primary and secondary lymphedema. Lymphat Res Biol 2008; 6(2): 65-8.

8. Ferrell RE, Baty CJ, Kimak MA, Karlsson JM, Lawrence EC, Franke- 
Snyder M, Meriney SD, Feingold E, Finegold DN. GJC2 missense mutations cause human lymphedema. Am J Hum Genet 2010; 86(6): 943-8.

9. Gordon K, Schulte D, Brice G, Simpson MA, Roukens MG, van Impel A, Connell F, Kalidas K, Jeffery S, Mortimer PS, Mansour S Schulte-Merker S, Ostergaard P. Mutation in vascular endothelial growth factor-c, a ligand for vascular endothelial growth factor receptor-3, is associated with autosomal dominant milroy-like primary lymphedema. Circ Res 2013; 112(6): 956-60.

10. Gonzalez-Garay ML, Aldrich MB, Rasmussen JC, Guilliod R, Lapinski PE, King PD, Sevick-Muraca EM. A novel mutation in CELSR1 is associated with hereditary lymphedema. Vasc Cell 2016; 8:1.

11. Fang J, Dagenais SL, Erickson RP, Arlt MF, Glynn MW, Gorski JL, Seaver LH, Glover TW. Mutations in FOXC2 (MFH-1), a forkhead family transcription factor, are responsible for the hereditary lymphedema-distichiasis syndrome. Am J Hum Genet 2000; 67(6): 1382-8.

12. Ostergaard $P$, Simpson MA, Connell FC, Steward CG, Brice G, Woollard WJ, Dafou D, Kilo T, Smithson S, Lunt P, Murday VA Hodgson S, Keenan R, Pilz DT, Martinez-Corral I, Makinen T, Mortimer PS, Jeffery S, Trembath RC, Mansour S. Mutations in GATA2 cause primary lymphedema associated with a predisposition to acute myeloid leukemia (Emberger syndrome). Nat Genet 2011; 43(10): 929-31.

13. Irrthum A, Devriendt $K$, Chitayat D, Matthijs G, Glade C, teijlen PM, Fryns JP, Van Steensel MA, Vikkula M. Mutations in the transcription factor gene SOX18 underlie recessive and dominant forms of hypotrichosis-lymphedema-telangiectasia. Am J Hum Genet 2003; 72(6): 1470-8.

14. Ostergaard $P$, Simpson MA, Mendola A, Vasudevan $P$, Connell FC, van Impel A, Moore AT, Loeys BL, Ghalamkarpour A, Onoufriadis A, Martinez-Corral I, Devery S, Leroy JG, van Laer L, Singer A Bialer MG, McEntagart M, Quarrell O, Brice G, Trembath RC, Schulte-Merker S, Makinen T, Vikkula M, Mortimer PS, Mansour $\mathrm{S}$, Jeffery S. Mutations in KIF11 cause autosomal-dominant microcephaly variably associated with congenital lymphedema and chorioretinopathy. Am J Hum Genet 2012; 90(2): 356-62.

15. Brice G, Ostergaard P, Jeffery S, Gordon K, Mortimer P, Mansour S. A novel mutation in GJA1 causing oculodentodigital syndrome and primary lymphoedema in a three generation family. Clin Genet 2013; 84(4): 378-81.

16. Martin-Almedina S, Martinez-Corral I, Holdhus R, Vicente A, Fotiou E, Lin S, Petersen K, Simpson MA, Hoischen A, Gilissen C, Jeffery H, Atton G, Karapouliou C, Brice G, Gordon K, Wiseman JW, Wedin M, Rockson SG, Jeffery S, Mortimer PS, Snyder MP, Berland S, Mansour S, Makinen T, Ostergaard P. EPHB4 kinase - inactivating mutations cause autosomal dominant lymphatic-related hydrops fetalis. J Clin Invest 2016; 126(8): 3080-8.

17. Tartaglia M, Kalidas K, Shaw A, Song X, Musat DL, van der Burgt I, Brunner HG, Bertola DR, Crosby A, Ion A, Kucherlapati RS, Jeffery $\mathrm{S}$, Patton MA, Gelb BD. PTPN11 mutations in Noonan syndrome: molecular spectrum, genotype-phenotype correlation, and phenotypic heterogeneity. Am J Hum Genet 2002; 70(6): 1555-63.

18. Morcaldi G, Bellini T, Rossi C, Maghnie M, Boccardo F, Bonioli E, Bellini C. Lymphodysplasia and KRAS mutation: a case report and literature review. Lymphology 2015; 48(3): 121-7.

19. Ekvall S, Wilbe M, Dahlgren J, Legius E, van Haeringen A, Westphal $\mathrm{O}$, Annerén G, Bondeson ML. Mutation in NRAS in familial Noonan syndrome - case report and review of the literature. BMC Med Genet 2015; 16: 95.

20. Milosavljević D, Overwater E, Tamminga S, de Boer K, Elting MW, van Hoorn ME, Rinne T, Houweling AC. Two cases of RIT1 associated Noonan syndrome: further delineation of the clinical phenotype and review of the literature. Am J Med Genet Part A 2016; 170(7):1874-80.

21. Allanson JE, Roberts AE. Noonan Syndrome. (2001 Nov 15 (updated 2016 Feb 25). In: Adam MP, Ardinger HH, Pagon RA, Wallace SE, Bean LJH, Stephens K, Amemiya A, editors. GeneReviews ${ }^{\circledast}$ (Internet). Seattle (WA): University of Washington, Seattle; 1993-2018.

22. Hanson HL, Wilson MJ, Short JP, Chioza BA, Crosby AH, Nash RM, Marks KJ, Mansour S. Germline CBL mutation associated with a noonan-like syndrome with primary lymphedema and teratoma associated with acquired uniparental isodisomy of chromosome 11q23. Am J Med Genet A 2014; 164A(4): 1003-9.
23. Lo IFM, Brewer C, Shannon N, Shorto J, Tang B, Black G, Soo MT, $\mathrm{Ng}$ DK, Lam ST, Kerr B. Severe neonatal manifestations of Costello syndrome. J Med Genet 2008; 45(3): 167-71.

24. Joyce S, Gordon K, Brice G, Ostergaard P, Nagaraja R, Short J, Moore S, Mortimer P, Mansour S. The lymphatic phenotype in Noonan and cardiofaciocutaneous syndrome. Eur J Hum Genet 2016; 24(5): 690-96.

25. Au AC, Hernandez PA, Lieber E, Nadroo AM, Shen YM, Kelley KA, Gelb BD, Diaz GA. Protein tyrosine phosphatase PTPN14 is a regulator of lymphatic function and choanal development in humans. Am J Hum Genet 2010; 87(3): 436-44.

26. Alders M, Hogan BM, Gjini E, Salehi F, Al-Gazali L, Hennekam EA Holmberg EE, Mannens MM, Mulder MF, Offerhaus GJ, Prescott TE, Schroor EJ, Verheij JB, Witte M, Zwijnenburg PJ, Vikkula M, Schulte-Merker S, Hennekam RC. Mutations in CCBE1 cause generalized lymph vessel dysplasia in humans. Nat Genet 2009; 41(12): 1272-74.

27. Alders M, Al-Gazali L, Cordeiro I, Dallapiccola B, Garavelli L, Tuysuz B, Salehi F, Haagmans MA, Mook OR, Majoie CB, Mannens MM, Hennekam RC. Hennekam syndrome can be caused by FAT4 mutations and be allelic to Van Maldergem syndrome. Hum Genet 2014; 133(9): 1161-67.

28. Fotiou E, Martin-Almedina S, Simpson MA, Lin S, Gordon K, Brice G, Atton G, Jeffery I, Rees DC, Mignot C, Vogt J, Homfray T, Snyder MP, Rockson SG, Jeffery S, Mortimer PS, Mansour S, Ostergaard $P$. Novel mutations in PIEZO1 cause an autosomal recessive generalized lymphatic dysplasia with non-immune hydrops fetalis. Nat Commun 2015; 6:8085.

29. Brouillard P, Dupont L, Helaers R, Coulie R, Tiller GE, Peeden J, Colige A, Vikkula M. Loss of ADAMTS3 activity causes Hennekam lymphangiectasia-lymphedema syndrome 3. Hum Mol Genet 2017; 26(21): 4095-04

30. Döffinger R, Smahi A, Bessia C, Geissmann F, Feinberg J, Durandy A, Bodemer C, Kenwrick S, Dupuis-Girod S, Blanche S, Wood P, Rabia SH, Headon DJ, Overbeek PA, Le Deist F, Holland SM, Belani K, Kumararatne DS, Fischer A, Shapiro R, Conley ME, Reimund E, Kalhoff H, Abinun M, Munnich A, Israël A, Courtois G, Casanova JL. $X$-linked anhidrotic ectodermal dysplasia with immunodeficiency is caused by impaired NF-kB signaling. Nat Genet 2001; 27 (3): 277-85.

31. Macmurdo CF, Wooderchak-Donahue W, Bayrak-Toydemir P, Le J, Wallenstein MB, Milla C, Teng JM, Bernstein JA, Stevenson DA RASA1 somatic mutation and variable expressivity in capillary malformation/arteriovenous malformation (CM/AVM) syndrome. Am J Med Genet A. 2016; 170(6): 1450-54.

32. Burrows PE, Gonzalez-Garay ML, Rasmussen JC, Aldrich MB, Guilliod R, Maus EA, Fife CE, Kwon S, Lapinski PE, King PD, SevickMuraca EM. Lymphatic abnormalities are associated with RASA1 gene mutations in mouse and man. Proc Natl Acad Sci U S A. 2013; 110(21): 8621-26.

33. Ma GC, Liu CS, Chang SP, Yeh KT, Ke YY, Chen TH, Wang BB, Kuo SJ, Shih JC, Chen M. A recurrent ITGA9 missense mutation in human fetuses with severe chylothorax: possible correlation with poor response to fetal therapy. Prenat Diagn. 2008; 28(11): 1057-63.

34. Luks VL, Kamitaki N, Vivero MP, Uller W, Rab R, Bovée JV, Rialon KL, Guevara CJ, Alomari Al, Greene AK, Fishman SJ, Kozakewich HP, Maclellan RA, Mulliken JB, Rahbar R, Spencer SA, Trenor CC 3rd, Upton J, Zurakowski D, Perkins JA, Kirsh A, Bennett JT, Dobyns WB, Kurek KC, Warman ML, McCarroll SA, Murillo R. Lymphatic and other vascular malformative/overgrowth disorders are caused by somatic mutations in PIK3CA. J Pediatr 2015;166(4): 1048-54.e1-5.

35. Lindhurst MJ, Sapp JC, Teer JK, Johnston JJ, Finn EM, Peters K, Turner J, Cannons JL, Bick D, Blakemore L, Blumhorst C, Brockmann K, Calder P, Cherman N, Deardorff MA, Everman DB, Golas G, Greenstein RM, Kato BM, Keppler-Noreuil KM, Kuznetsov SA, Miyamoto RT, Newman K, Ng D, O'Brien K, Rothenberg S, Schwartzentruber DJ, Singhal V, Tirabosco R, Upton J, Wientroub S, Zackai EH, Hoag K, Whitewood-NealT, Robey PG, Schwartzberg PL, Darling TN, Tosi LL, Mullikin JC, Biesecker LG. A mosaic activating mutation in AKT1 associated with the Proteus syndrome. N Engl J Med 2011; 365(7): 611-19.

36. Adam MP, Ardinger HH, Pagon RA, Wallace SE, Bean LJH, Stephens K, Amemiya A, editors. GeneReviews. Seattle (WA): University of Washington, Seattle; 1993-2018. Available from: http://www.ncbi. nlm.nih.gov/pubmed/20301295. 